Zwartouw, H. T. \& Smith, H. (1956). J. gen. Microbiol. 15, 261-265

\title{
Non-identity of the Phospholipase of Bacillus anthracis with the Anthrax Toxin
}

\author{
By H. T. ZWARTOUW AND H. SMITH \\ The Microbiological Research Establishment, Porton, Wiltshire
}

\begin{abstract}
SUMMARY : Filtrates from suitable cultures of Bacillus anthracis contain a phospholipase which slowly hydrolyses the phospholipid in egg-yolk broth but has no action on free egg-lecithin. This enzyme does not appear to be the anthrax toxin.
\end{abstract}

McGaughey \& Chu (1948) showed that Bacillus anthracis produced an opalescence when growing in a medium containing egg yolk, but the effect was less than that produced by B.cereus and B. mycoides. B. anthracis growing in the blood of infected guinea-pigs produces an extracellular toxin which kills the host in secondary shock (Smith, Keppie, Stanley \& Harris-Smith, 1955; Smith, Keppie \& Stanley, 1955); a lethal amount of this toxin is only produced by the growth of a large number of organisms in the blood during the terminal phase of anthrax. Lecithinases, responsible for the egg-yolk reaction of certain bacteria, are involved in their toxigenicity (MacFarlane, 1955) and when injected can produce the symptoms of shock (Berg, Levinson \& Wang, 1951). A possible relationship between the egg-yolk reaction and the toxin of $B$. anthracis has therefore been investigated. First, the egg-yolk reaction was examined to see whether the opalescence produced by $\boldsymbol{B}$. anthracis was due to an extracellular product of the organism and whether this product was a lecithinase. Then, the toxic plasma of infected guinea-pigs was investigated for the presence of such an enzyme and for a connexion between it and the toxic action.

\section{METHODS}

Organism. A spore suspension of Bacillus anthracis, strain N.P., as used in all previous work (Smith et al. 1955) was the source of organisms.

Egg-yolk broth (E.ч.в.). Two egg yolks/l. $1 \%$ peptone solution containing $0 \cdot 5 \% \mathrm{NaCl}$ and at $\mathrm{pH} \mathbf{7 \cdot 4}$.

Plasma containing the anthrax toxin. This was collected from guinea-pigs dying of anthrax as described by Smith et al. (1955).

Anthrax antiserum. This was prepared in the horse by injecting the 'Sterne' strain of Bacillus anthracis (Belton \& Strange, 1954).

Test for phospholipase activity. A sterile mixture of the solution to be tested ( $2 \mathrm{ml}$.) and E.Y.B. ( $2 \mathrm{ml}$., containing $c .50 \mu \mathrm{g}$. ether-soluble $\mathrm{P}$ ) was incubated at $37^{\circ}$ and $\mathrm{pH} 7 \cdot 4$. After cooling the mixture, it was extracted with ether $(3 \mathrm{ml}$.) and the $\mathrm{P}$ content of the ethereal extract determined by the method of Fiske \& SubbaRow (1925). Activities are expressed as the percentage decrease in the ether-soluble $\mathbf{P}$ produced by the test materials in a stated time. Controls incubated for $72 \mathrm{hr}$. at $37^{\circ}$ did not show a decrease in ether-soluble $\mathrm{P}$. 


\section{RESULTS}

The egg-yolk reaction with the growing organism

E.Y.B. was inoculated with Bacillus anthracis and incubated at $37^{\circ}$ for 4 days. The culture was then opalescent; centrifugation deposited the bacteria and produced a layer of fat on top of the clear medium. In three experiments the ether-soluble $\mathbf{P}$ of the medium was decreased $90 \%$ by the growth of the organism.

\section{Culture filtrates with phospholipase activity}

Preparation. Media (E.ч.в., $1 \%$ peptone or tryptic meat broth; $100 \mathrm{ml}$.) were inoculated with $6 \times 10^{7}$ spores and incubated at $37^{\circ}$ and $\mathrm{pH} 7 \cdot 4$ in a tlask $(250 \mathrm{ml}$.) for 2 days. After filtration through 'Millipore' filters (Lovell Chemical Co., Mass., U.S.A.) the sterile filtrate was stored at $0^{\circ}$.

Selection of medium. Table 1 shows the results of tests for phospholipase activity on filtrates from cultures of Bacillus anthracis in E.x.B., $1 \%$ peptone and tryptic meat broth. Filtrates from cultures in E.Y.B. and $1 \%$ peptone were consistently active but cultures in tryptic meat broth т.м.в. had a much smaller and variable activity. Filtrates from cultures in $1 \%$ peptone were used in the following work.

Table 1. Phospholipase activity of culture filtrates from different media Phospholipase activity*

\begin{tabular}{lccc}
\multicolumn{4}{c}{ Decrease $(\%)$ in ether soluble } \\
Culture medium & $24 \mathrm{hr}$ & $48 \mathrm{hr}$. \\
E.y.B. & $(1)$ & 61 & 81 \\
& $(2)$ & 83 & 90 \\
Peptone (1) & 90 & 95 \\
T.M.B. & $(1)$ & 79 & 90 \\
& $(1)$ & 6 & 9 \\
(2) & 14 & 34
\end{tabular}

* For details of test for phospholipase activity see text.

Activity. Table 2 shows the slow progressive decrease with time of the ethersoluble $\mathbf{P}$ of E.Y.B. when the culture filtrate was examined in the test for phospholipase activity.

Effect of pH. In $8 \mathrm{hr}$. a culture filtrate decreased the ether-soluble $\mathbf{P}$ of E.Y.в. by $10,14,35,35$ and $18 \%$ when examined at values of $\mathrm{pH} 5 \cdot 6,6 \cdot 7,7 \cdot 4$, $8 \cdot 0$ and $8 \cdot 8$, respectively, in the test for phospholipase activity.

Effect of calcium. The mixture of E.Y.B. and peptone culture filtrate used in the phospholipase test contained $c .0 .001 \mathrm{~m}-\mathrm{Ca}^{++}$. Increase of the $\mathrm{Ca}^{++}$concentration to $0.003,0.006,0.01$ and $0.05 \mathrm{M}$ did not increase the phospholipase activity, although addition of a high concentration of sodium citrate $(0 \cdot 1 \mathrm{M})$ decreased it. 
Stability. There was no loss in phospholipase activity on storage at $0-4^{\circ}$ for several weeks. No appreciable loss in activity occurred after heating the culture filtrate to $60^{\circ}$ for $1 \mathrm{hr}$., but heating at $100^{\circ}$ for the same period destroyed the activity. After shaking with ballotini beads and air for $16 \mathrm{hr}$. at $0-4^{\circ}$ the activity was decreased about $50 \%$.

Table 2. The progressive decrease of ether soluble $\mathrm{P}$ when a peptone culture filtrate was incubated with egg-yolk broth at $\mathrm{pH} 7 \cdot 4$ and $37^{\circ}$

$\begin{array}{cc}\begin{array}{c}\text { Time of } \\ \text { incubation } \\ \text { (hr.) }\end{array} & \begin{array}{c}\text { Decrease }(\%) \\ \text { of ether } \\ \text { soluble P }\end{array} \\ 4 & 9 \\ 8 & 26 \\ 12 & 47 \\ 16 & 53 \\ 18 & 66 \\ 21 & 76 \\ 24 & 79 \\ 32 & 88 \\ 41 & 98\end{array}$

Specificity. Active culture filtrates did not liberate inorganic phosphate from solutions $(0 \cdot 1 \%)$ of sodium $\alpha$ - and $\beta$-glycerophosphates or adenylic acid. Sodium monophenyl phosphate was slowly hydrolysed; under the conditions of the test for phospholipase activity in which the E.Y.B. was replaced by a solution $(0 \cdot 1 \%)$ of sodium monophenyl phosphate, the $\mathrm{P}$ set free as inorganic phosphate in $72 \mathrm{hr}$. (about $15 \%$ of the total P) was far less than the decrease of ether-soluble $\mathbf{P}$ in a normal phospholipase test.

The culture filirates did not hydrolyse either lecithin (egg) or cephalin (sheep brain). The tests were carried out as in the test for phospholipase activity, i.e. at $\mathrm{pH} 7 \cdot 4$ and $37^{\circ}$ for $48 \mathrm{hr}$. with E.Y.B. replaced by aqueous emulsions $(0 \cdot 2 \%)$ of lecithin or cephalin. The addition of $\mathrm{Ca}^{++}(0.002 \mathrm{M}$ and $0.005 \mathrm{M})$ did not affect hydrolysis of the lecithin. No haemolysis or increase in fragility of guinea-pig erythrocytes was produced when they were incubated with culture filtrates for $24 \mathrm{hr}$. at $37^{\circ}$.

Table 3. The effect of anthrax antiserum on phospholipase activity Phospholipase activity

\begin{tabular}{|c|c|c|}
\hline \multirow[b]{2}{*}{ Material } & \multicolumn{2}{|c|}{$\begin{array}{c}\text { Decrease }(\%) \text { in ether soluble } \\
\mathbf{P} \text { during } 24 \mathrm{hr} \text {. }\end{array}$} \\
\hline & No addition & $\begin{array}{l}\text { With antiserum } \\
(0.3 \mathrm{ml} .)^{*}\end{array}$ \\
\hline Control of normal plasma $(0.3 \mathrm{ml}$. $)$ & 8 & 19 \\
\hline Toxic plasma $(0.3 \mathrm{ml})$. & 98 & 100 \\
\hline E.Y.B. culture filtrate $(2 \mathrm{ml})$. & 91 & 98 \\
\hline Peptone culture filtrate $(2 \mathrm{ml}$.) & 82 & 95 \\
\hline
\end{tabular}

* This quantity of antiserum neutralized $9 \mathrm{ml}$. of toxic plasma (Smith, Keppie \& Stanley, 1955). 
Absence of a connexion between the phospholipase and the anthrax toxin

The active culture filtrates did not produce oedema when injected into the skin of a guinea-pig as did the toxic plasma of guinea-pigs dying of anthrax. The toxic plasma had a higher phospholipase activity than the non-toxic culture filtrates; $\mathbf{0 . 3} \mathrm{ml}$. of toxic plasma had approximately the same activity as $2 \mathrm{ml}$. of culture filtrate. However, Table 3 shows that neither the phospholipase activity of the toxic plasma nor that of the culture filtrates was inhibited by an amount of anthrax antiserum which was in excess of that required to completely neutralize the toxic action of the plasma.

\section{DISCUSSION}

McGaughey \& Chu (1948) could not detect an enzyme responsible for the eggyolk reaction in culture filtrates of Bacillus anthracis. Contrary to this, we have found that filtrates from cultures in suitable media do contain such an enzyme, although the activity is small. The enzyme did not attack purified egg-lecithin. The hydrolysis of phospholipid by the enzyme may be dependent on the 'combined' state of the substrate in E.Y.B. It is relevant to point out here that lecithinase preparations from Bacillus cereus and Clostridium welchii, which hydrolysed equal amounts of free phospholipid, differed greatly in their ability to hydrolyse lipovitellenin (Chu, 1949). The phospholipase of $B$. anthracis resembles bacterial lecithinases in being fairly stable to heat and sensitive to surface denaturation.

Plasma containing the anthrax toxin also contains a phospholipase, but the two are probably not connected since anthrax antitoxin did not inhibit the phospholipase activity of the toxic plasma or of culture filtrates. In the case of lecithinase preparations from Clostridium welchii and Bacillus cereus, both the egg-yolk reaction and the toxicity are inhibited by the same homologous antiserum (MacFarlane, 1955; Chu, 1949).

This work was part of a thesis submitted by one of us (H.T.Z.) for the Ph.D. degree of the University of London.

\section{REFERENCES}

Belton, F. C. \& Strange, R. E. (1954). Studies on a protective antigen produced in vitro from Bacillus anthracis; medium and methods of production. Brit. $J$. exp. Path. 35, 144.

Berg, M., Levinson, S. A. \& WANG, K. J. (1951). Effect of experimental shock induced by Clostridium perfringens toxin on the kidneys of dogs. Arch. Path. 51, 137.

CHU, H. P. (1949). The lecithinase of Bacillus cereus and its comparison with Clostridium welchii $\alpha$-toxin. J. gen. Microbiol. 3, 255.

Fiske, C. H. \& SubbaRow, Y. (1925). The colorimetric determination of phosphorus. J. biol. Chem. 66, 375 .

MacFarlane, M. G. (1955). On the biochemical mechanism of action of gas gangrene toxins. In Mechanisms of Microbial Pathogenicity. Symp. Soc. gen. Microbiol. 5, 57. 
McGaughey, C. A. \& Chu, H. P. (1948). The egg-yolk reaction of aerobic sporing bacilli. J. gen. Microbiol. 2, 334.

Smith, H., Keppie, J., Stanley, J. L. \& Harris-Smith, P. W. (1955). The chemical basis of the virulence of Bacillus anthracis. IV. Secondary shock as the major factor in death of guinea pigs from anthrax. Brit. J. exp. Path. 36, 323.

Smith, H., Keppie, J. \& Stanley, J. L. (1955). The chemical basis of the virulence of Bacillus anthracis. V. The specific toxin produced by $B$. anthracis in vivo. Brit. J. exp. Path. 36, 460.

(Received 11 January 1956) 